\title{
75 years of agricultural plant breeding
}

"Breeding and selection for northern crop margins» is the theme for this special issue of the Journal of Agricultural Science in Finland, issued on the occasion of the 75th year of activity of The Hankkija Plant Breeding Institute. The choice of topic indicates the work of this Institute, i.e. to promote the reliability of crop production in the world's northernmost region of agriculture.

In addition to our own research staff, the authors include plant breeders and scientists from various domestic and foreign institutes. Each writer works on the northern frontier of his crop species, and is seeking solutions for breeding plants with high adaptibility to the extremity of the growing environment. The articles deal with a wide range of cultivated plants, from perennial grasses and overwin- tering rye to annual field crops, small fruits and decorative rhododendrons.

The Hankkija Agricultural Cooperative was established by Finnish farmers in 1905. Its plant breeding activity started in 1913, the aim being to serve the development of Finnish agricultural production by providing highly adapted varieties originating from targetoriented breeding programmes. In the beginning of this century, a few foreign-bred cultivars were known only in the south of Finland, whereas the non-bred local varieties, even of cereals, were dominant.

Almost all Finland lies north of the 60th parallel (Fig. 1). This fact determines the main goals of all plant breeding done in the country. The varieties which can be cultivated in our fields must be well adapted to the short

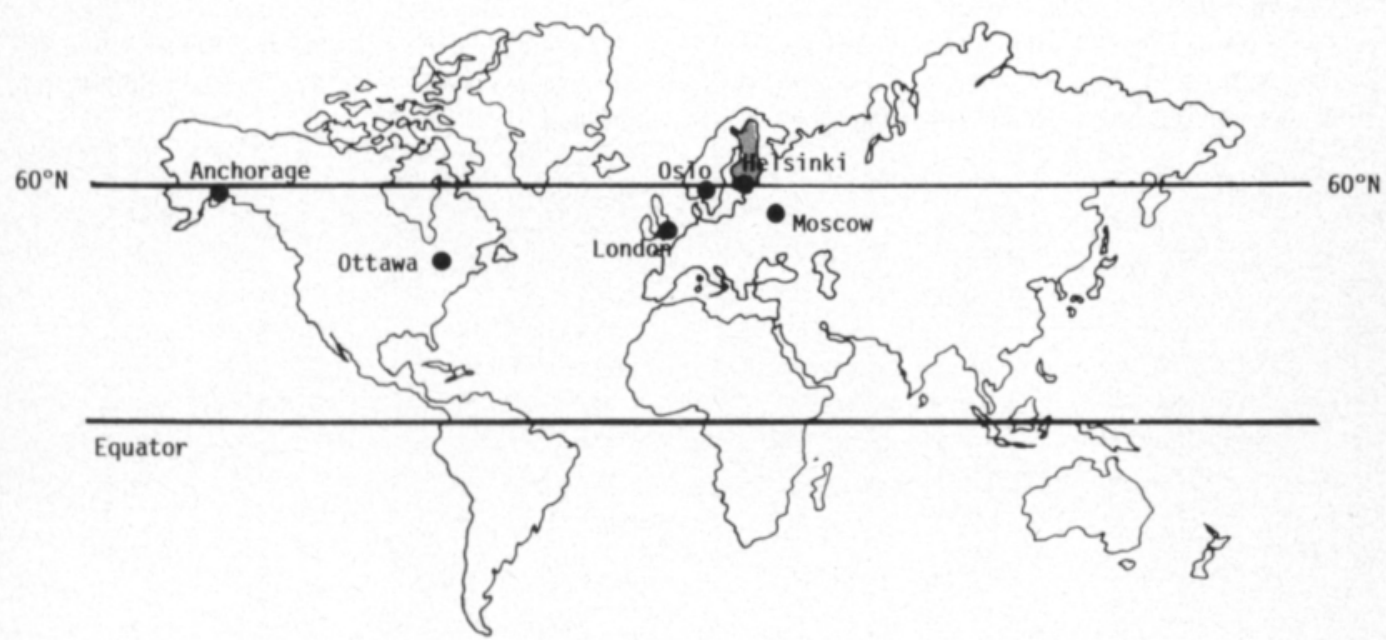

Fig. 1. The agricultural production of Finland is performed north of the 60th parallel, influenced varying by the Atlantic and the eastern continental climate. 
and relatively cool growing seasons with extreme photoperiodic conditions. The cold winters with a long-lasting snow cover heavily stress the genotypes of all biannual and perennial field crops.

Domestic plant breeding has played a decisive role in agricultural development. The result has been full self-sufficiency as regards the main field crops. The maintenance of this self-sufficiency is also the goal of future agricultural policy.

Altogether 109 varieties of 19 crop species have been released from the Hankkija Plant Breeding Institute. The variety list of the National Board of Agriculture for 1987 includes 26 varieties from our Institute. In 1985, $33 \%$ of the cereal acreage was sown with Hankkija varieties. In addition to cereals - spring and winter wheats, winter rye, spring barley and oats - the present breeding objects included in our breeding programme are her-

\section{SELOSTUS}

\section{5 vuotta lajikkeenjalostusta Hankkijan kasvinjalostuslaitoksella}

Tämä Maataloustieteellisen Aikakauskirjan numero on toimitettu vuonna 1913 perustetun Hankkijan kasvinjalostuslaitoksen 75-juhlavuoden merkeissä. Artikkelien yhteisteemana on "Jalostus ja valinta viljelyn pohjoisrajal- bage crops (timothy, meadow fescue, tall fescue and red clover), lawn species (meadow grass, red fescue and bent), oil crops (spring turnip rape and spring rape) and seed legumes (pea and faba bean).

Cultivars bred and selected for the extremely northern conditions are seldom competitive in more southerly fields. However, a few of our varieties have been widely cultivated abroad: the Olli barley (released in 1927) in Canada, the barley varieties Tammi (1938), Pirkka (1952) and Otra (1959) in the USSR, and Sisu oats (1948) in Sweden. International attention has now been paid to Hankkija's semileafless protein peas. Of them, the variety Helka (1987) is being cultivated or is undergoing official trials in several European countries.

\section{E.I. Kivi}

Director of the Institute la». Jokainen kirjoittaja tyőskentelee lajin tai kasviryhmăn viljelyn pohjoisella raja-alueella ja käsittelee sen asettamia ongelmia kohteensa jalostamisessa tai jalostustutkimuksessa. 